\title{
Influences of Peer Support Group and Psychosocioeconomic Determinants on Treatment Compliance in HIV/AIDS Patients: A Path Analysis Evidence from Sragen, Central Java
}

\author{
Yusuf Bachtiyar Lobis'), Bhisma Murti'), Hanung Prasetya2) \\ 1)Masters Program in Public Health, Universitas Sebelas Maret \\ ${ }^{2}$ School of Health Polytechnics, Ministry of Health Surakarta
}

\section{ABSTRACT}

Background: Human Immunodeficiency Virus (HIV) is a virus that attacks the immune system, which further weakens the body's ability to fight infection and disease. AIDS (Acquired Immune Deficiency Syndrome) is a condition in which $\mathrm{HIV}$ is already in the final infection stage. When a person has AIDS, the body no longer can fight the infection it causes. This study aims to determine the effect of peer support groups and psychosocial economic determinants on treatment compliance to people living with HIV / AIDS (PLWHA) in Sragen, Central Java.

Subjects and Method: This study was an observational analytic with a case-control design. This study was conducted in Sragen from February to April 2020. The sample was selected by fixed disease sampling as many as 200 study subjects with the criteria of PLWHA. The variables observed for effect were treatment compliance to PLWHA, peer support groups, family support, perceived benefits, perceived trust, perceived threats, perceived barriers, and learning through observation (Observational Learning). Data were collected using a questionnaire and analyzed using path analysis or path analysis with Stata version 14.

Results: Treatment compliance in PLWHA increased with perceived benefit $(b=1.10 ; 95 \%$
$\mathrm{CI}=0.41$ to $1.79 ; \mathrm{p}=0.002)$, perceived trust $(\mathrm{b}=$ 1.56; $95 \% \mathrm{CI}=0.85$ to 2.27 ; $<<0.001$ ), peer support group $(b=0.66 ; 95 \% \mathrm{CI}=-0.00$ to 1.33 ; $\mathrm{p}=0.051)$, family support $(\mathrm{b}=0.97 ; 95 \% \mathrm{CI}=0.28$ to $1.66 ; \mathrm{p}=0.006)$, perceived threat $(\mathrm{b}=0.97$; $95 \% \mathrm{CI}=0.28$ to $1.66 ; \mathrm{p}=0.006)$. Treatment compliance in PLWHA decreased with perceived inhibition $(b=-0.69 ; 95 \% \mathrm{CI}=-1.37$ to $-0.01 ; \mathrm{p}=$ 0.047). Treatment compliance in people living with HIV/AIDS was influenced indirectly by learning through observation.

Conclusion: Treatment compliance in PLWHA is directly influenced by perceived benefits, peer support groups, family support, perceived threats, perceived barriers. Treatment compliance in PLWHA is influenced indirectly by learning through observation.

Keywords: HIV/AIDS, compliance, peer support groups, psychosocial economics

Correspondence: Yusuf Bachtiyar Lobis. Program Studi Ilmu Kesehatan Masyarakat Pascasarjana Universitas Sebelas Maret, Jl. Ir. Sutami No. 36A, Surakarta 57126, Indonesia. Email: bachtiyaro3@gmail.com. Mobile: +628111388841 .

\section{Cite this as:}

Lobis YB, Murti B, Prasetya H (2020). Influences of Peer Support Group and Psychosocioeconomic Determinants on Treatment Compliance in HIV/AIDS Patients: A Path Analysis Evidence from Sragen, Central Java. J Epidemiol Public Healt. 05(03): 348-358. https://doi.org/10.26911/jepublichealth.2020.05.03.09.

cc (i) (-) Journal of Epidemiology and Public Health is licensed under a Creative Commons Attribution-Non Commercial-Share Alike 4.o International License.

\section{BACKGROUND}

Infectious diseases in Indonesia are becoming increasingly difficult to control, especially those with HIV/AIDS. Human Immunodeficiency Virus, abbreviated as HIV, is a virus that causes Acquired Immuno Deficiency Syndrome (AIDS). Acquired Immunodeficiency Syndrome, hereinafter referred to as AIDS, is a collection of symptoms of reduced self-defense ability caused by the entry of the 
Lobis et al./ Peer Support Group and Psychosocioeconomic Determinants on Treatment Compliance

HIV in a person's body. People with HIV and AIDS (PLWHA) have been infected with the HIV (Ministry of Health of the Republic of Indonesia, 2013).

Data on HIV/AIDS cases in Indonesia are based on cumulative reports from the Directorate General of P2P, Ministry of Health of the Republic of Indonesia from 1987-2016 as many as 291,465 cases with the highest cases namely DKI Jakarta with 50,053 cases, East Java 44,006 cases, Papua 35,764 cases, West Java 24,927 cases, and Central Java 20,132 cases. Data on HIV/AIDS cases in 2017 were 46,405 cases so that the cumulative total of HIV/AIDS cases from 1987-2017 recorded and reported in Indonesia was 337,870 cases (Ministry of Health RI, 2018).

Sragen Health Office reported that HIV/AIDS cases in Sragen Regency, Central Java, have increased every year. The last recorded and reported case data was in 2017 , spread evenly in 20 sub-districts in Sragen, Central Java, consisting of 81 HIV sufferers and 106 AIDS sufferers, while 18 sufferers died of HIV/AIDS (Sragen District Health Profile, 2017). HIV/AIDS data in Sragen, Central Java, based on the last five years, has increased. In 2014, it was 100 cases, 2015 as many as 173 cases, 2016 as many as 163 cases, 2017 as many as 187 cases, and in 2018 as many as 227 cases. The number of cases from 2000 to August 2019 was 1,018 cases (Sragen Health Office, 2019).

Support from groups such as Peer Support Groups (PSG) is a group of people living with HIV / AIDS (PLWHA) and people living with PLWHA. Peer support is mental support provided by PLWHA to other PLWHA, especially PLWHA who have just found out about their HIV status. PSG has a significant role in the quality of life of PLWHA. PLWHA, who get peer support, affect higher self-confidence levels, knowledge of HIV, access to HIV services, HIV prevention behavior, and positive activities compared to PLWHA. The latter do not get peer support (Johan et al., 2014).

A study on treatment compliance to PLWHA observed from peer support groups and psychosocial economics to determine the effect on treatment compliance in PLWHA has never been done in Sragen. Therefore, the authors were interested in conducting this study.

\section{SUBJECTS AND METHOD}

\section{Study Design}

This study was an analytic observational research study with a case-control approach using a path analysis model.

\section{Population dan Sample}

The population of this study was people PLWHA who were recorded and reported in Sragen, Central Java.

\section{Study Variables}

The variables observed in this study were treatment compliance in PLWHA, peer support groups, family support, perceived benefits, perceived beliefs, perceived threats, perceived barriers, and learning through observation (Observational Learning).

\section{Operational Definition of Variables Treatment compliance in PLHWA was} compliance seen in PLHWA behavior by the provisions given by health workers. The measuring instrument used was a questionnaire. The data scale used was continuous, and to facilitate analysis, the data was converted into a dichotomy. Code $\mathrm{O}=$ low and code $1=$ high .

Peer Support Groups were cooperative in the care and treatment of PLWHA and actively participated in the prevention of $\mathrm{HIV} /$ AIDS transmission. The measuring instrument used was a questionnaire. The data scale used was continuous, and to facilitate analysis, the data was converted into a dichotomy. Code $\mathrm{O}=$ weak and $1=$ strong. 
Lobis et al./ Peer Support Group and Psychosocioeconomic Determinants on Treatment Compliance

Family Support was the respondent's perception of the family's support, including emotional support, information support, instrumental support, appreciation support, and social network support. The measuring instrument used was a questionnaire. The data scale used was continuous, and to facilitate analysis, the data was converted into a dichotomy. Code $\mathrm{O}=$ weak and $1=$ strong.

Perceived benefits were the benefit felt by PLWHA regarding HIV/AIDS understanding, HIV/AIDS transmission, and HIV/AIDS prevention. The measuring instrument used was a questionnaire. The data scale used was continuous, and to facilitate analysis, the data was converted into a dichotomy. Code $\mathrm{O}=$ low and $1=$ high .

Perceived trust was the self-confidence that PLWHA feels about the need for safety and security, quality of life, a sense of being respected by others. The measuring instrument used was a questionnaire. The data scale used was continuous and to facilitate data analysis becomes a dichotomy. Code $\mathrm{o}=$ low and $1=$ high .

Perceived threats were the threat felt by PLWHA to the transmission of HIV / AIDS. The measuring instrument used was a questionnaire. The data scale used was continuous, and to facilitate analysis, the data was converted into a dichotomy. Code $\mathrm{O}=$ low and $1=$ high .

Perceived barriers were the obstacles felt by PLWHA regarding the information they get about HIV/AIDS. The measuring instrument used was a questionnaire. The data scale used was continuous, and to facilitate analysis, the data was converted into a dichotomy. Code $0=$ low and $1=$ high .

Observational Learning was the strengthening of learning obtained from observing or witnessing the actions of others. The measuring instrument used was a questionnaire. The data scale used was continuous, and to facilitate analysis, the data was converted into a dichotomy. Code $\mathrm{O}=$ low and $1=$ high .

\section{Study Instruments}

The instrument in this study used a questionnaire. The questionnaire was in the form of a closed questionnaire. The researcher had provided the answers in the questionnaire so that the respondent only needed to choose and fill in according to reality.

\section{Data Analysis}

Univariate analysis was used to describe each dependent variable and the independent variables. Data were grouped according to the data type. Continuous data were presented with mean, standard deviation, minimum and maximum values. The dichotomy data was entered into the frequency distribution table.

Bivariate analysis was used to determine the correlation between the independent and dependent variables using the chisquare test.

Multivariate analysis was used to explain the correlation of influence between variables. Multivariate analysis was carried out by path analysis.

\section{Research Ethic}

This study focused on the basic principles of research ethics and applied for ethical permission from the Health Research Ethics Commission of Dr. Moewardi with the Ethical Eligibility Number Number: 211/II/ HREC / 2020 on February 7, 2020.

\section{RESULTS}

\section{A. Univariate analysis}

Univariate analysis is described in Tables 1 and 2. Table 1 shows the sample measurements for 200 subjects in PLWHA who met the inclusion criteria. Treatment compliance variable in PLWHA had a mean $=5.71$ and $\mathrm{SD}=2.22$ with a minimum value of 1 and a maximum of 10 . The peer support group variable had a mean $=2.8$ and $\mathrm{SD}=1.45$ with a minimum value of $\mathrm{o}$ and $\mathrm{a}$ maximum of 6 . The family support variable had 
Lobis et al./ Peer Support Group and Psychosocioeconomic Determinants on Treatment Compliance

a mean $=3.32$ and $\mathrm{SD}=1.57$ with a minimum value $=1$ and a maximum $=6$. The perceived benefit variable had a mean $=2.81$ and $\mathrm{SD}=$ 0.96 with a minimum value $=0$ and $a$ maximum $=4$. The perceived belief variable had a mean 2.76 and $\mathrm{SD}=0.85$ with a minimum value 0 and maximum $=4$. The perceived threat variable had a mean $=2.58$ and $\mathrm{SD}=1.16$ with a minimum value $=0$ and a maximum $=5$. The perceived barrier variable had a mean $=2.57$ and $\mathrm{SD}=1.09$ with a minimum value $=0$ and $\mathrm{a}$ maximum value $=5$.

The learning variable through observation had a mean $=2.63$ and $\mathrm{SD}=1.02$ with a minimum value $=0$ and a maximum $=5$.

Table 1. Subject characteristics (continuous data)

\begin{tabular}{lccccc}
\hline \multicolumn{1}{c}{ Characteristics } & n & Mean & SD & Min. & Max. \\
\hline PLWHA Treatment Compliance & 200 & 5.71 & 2.22 & 1 & 10 \\
Peer Support Groups & 200 & 2.85 & 1.45 & $\mathrm{O}$ & 6 \\
Family support & 200 & 3.32 & 1.57 & 1 & 6 \\
Perceived Benefits & 200 & 2.81 & 0.96 & $\mathrm{O}$ & 4 \\
Perceived Trust & 200 & 2.76 & 0.85 & $\mathrm{O}$ & 4 \\
Perceived Threat & 200 & 2.58 & 1.16 & $\mathrm{O}$ & 5 \\
Perceived Barriers & 200 & 2.57 & 1.09 & $\mathrm{O}$ & 5 \\
Learning Through Observation & 200 & 2.63 & 1.02 & $\mathrm{O}$ & 5 \\
\hline
\end{tabular}

Table 2. Subject characteristics (dichotomous data)

\begin{tabular}{lcc}
\hline Characteristics & n & \% \\
\hline Treatment compliance in PLWHA & 100 & 50 \\
Weak & 100 & 50 \\
Strong & & \\
Peer Support Groups & 112 & 39 \\
Weak & 88 & 61 \\
Strong & & \\
Family support & 76 & 38 \\
Weak & 124 & 62 \\
Strong & & \\
Perceived Benefits & 83 & 41.5 \\
Low & 117 & 58.5 \\
High & & 37 \\
Perceived Trust & 74 & 63 \\
Weak & 126 & 54 \\
Perceived Threat & & 46 \\
Weak & 108 & \\
Strong & 92 & 52 \\
Lerceived Barriers & & 48 \\
High & 104 & \\
Learning Through Observation & 96 & 41 \\
How & & 59 \\
\hline
\end{tabular}

Table 2 shows that most of the study subjects were mostly PLWHA who had weak peer support groups as much as $56 \%$ and strong family support as much as $61 \%$. The high perceived benefits were $58.5 \%$. A strong perceived belief was $63 \%$. The low perceived threat was 54\%. The low perceived barriers were $52 \%$, and learning through high observation was $59 \%$. 
Lobis et al./ Peer Support Group and Psychosocioeconomic Determinants on Treatment Compliance

\section{B. The result of bivariate analysis}

The analysis used in this study was the chisquare test, which explained the relationship between the dependent variable (Treatment Compliance for PLWHA) and one independent variable (Peer Support Group, Family
Support, Perceived Benefits, Perceived Trust, Perceived Threats, Perceived Barriers, and Learning Through Observation). The results of the bivariate analysis can be seen in Table 3 .

Table 3. Chi-square test of factors affecting treatment compliance in PLWHA

\begin{tabular}{|c|c|c|c|c|c|c|c|c|}
\hline \multirow{3}{*}{ Independent Variable } & \multicolumn{4}{|c|}{$\begin{array}{c}\text { PLWHA Treatment } \\
\text { Compliance }\end{array}$} & \multirow{2}{*}{\multicolumn{3}{|c|}{$95 \%$ CI }} & \multirow{3}{*}{$\mathbf{p}$} \\
\hline & \multicolumn{2}{|c|}{ Disobedient } & \multicolumn{2}{|c|}{ Obedient } & & & & \\
\hline & $\mathbf{N}$ & $\%$ & $\mathbf{N}$ & $\%$ & & $\begin{array}{l}\text { Lower } \\
\text { limit }\end{array}$ & $\begin{array}{l}\text { Upper } \\
\text { limit }\end{array}$ & \\
\hline \multicolumn{9}{|c|}{ Peer Support Groups (PGS) } \\
\hline Weak & 65 & 58.04 & 47 & 41.96 & \multirow{3}{*}{2.09} & \multirow{3}{*}{1.14} & \multirow{3}{*}{3.85} & \multirow{3}{*}{$<0.001$} \\
\hline Strong & 35 & 39.77 & 53 & 60.23 & & & & \\
\hline Family support & & & & & & & & \\
\hline Weak & 49 & 69.82 & 29 & 37.18 & \multirow[t]{2}{*}{2.35} & \multirow[t]{2}{*}{1.26} & \multirow{2}{*}{4.40} & \multirow[t]{2}{*}{$<0.001$} \\
\hline $\begin{array}{l}\text { Strong } \\
\text { Perceived benefits }\end{array}$ & 51 & 41.80 & 71 & 58.20 & & & & \\
\hline $\begin{array}{l}\text { Low } \\
\text { High }\end{array}$ & $\begin{array}{l}55 \\
45\end{array}$ & $\begin{array}{l}66.27 \\
38.46\end{array}$ & $\begin{array}{l}28 \\
72\end{array}$ & $\begin{array}{l}33.73 \\
61.54\end{array}$ & \multirow[t]{2}{*}{3.14} & \multirow[t]{2}{*}{1.68} & \multirow[t]{2}{*}{$5 \cdot 92$} & \multirow[t]{2}{*}{$<0.001$} \\
\hline Perceived Trust & & & & & & & & \\
\hline $\begin{array}{l}\text { Low } \\
\text { High }\end{array}$ & $\begin{array}{l}54 \\
46\end{array}$ & $\begin{array}{l}72.97 \\
36.51\end{array}$ & $\begin{array}{l}20 \\
80\end{array}$ & $\begin{array}{l}27.03 \\
63.29\end{array}$ & \multirow[t]{2}{*}{4.70} & \multirow[t]{2}{*}{2.40} & \multirow[t]{2}{*}{9.29} & \multirow[t]{2}{*}{$<0.001$} \\
\hline Perceived Threat & & & & & & & & \\
\hline $\begin{array}{l}\text { Low } \\
\text { High }\end{array}$ & $\begin{array}{l}66 \\
34\end{array}$ & $\begin{array}{c}61.11 \\
36.96\end{array}$ & $\begin{array}{l}42 \\
58\end{array}$ & $\begin{array}{l}38.89 \\
63.04\end{array}$ & \multirow[t]{2}{*}{2.68} & \multirow[t]{2}{*}{1.45} & \multirow[t]{2}{*}{4.96} & \multirow[t]{2}{*}{$<0.001$} \\
\hline Perceived Barriers & & & & & & & & \\
\hline $\begin{array}{l}\text { Low } \\
\text { High }\end{array}$ & $\begin{array}{c}15 \\
135\end{array}$ & $\begin{array}{l}25.86 \\
95.07\end{array}$ & $\begin{array}{c}43 \\
7\end{array}$ & $\begin{array}{c}76.14 \\
4.93\end{array}$ & \multirow[t]{2}{*}{0.01} & \multirow[t]{2}{*}{0.006} & \multirow[t]{2}{*}{0.05} & $<0.001$ \\
\hline Observational Learnir & & & & & & & & \\
\hline $\begin{array}{l}\text { Seldom } \\
\text { Often }\end{array}$ & $\begin{array}{c}115 \\
35\end{array}$ & $\begin{array}{l}89.84 \\
48.61 \\
\end{array}$ & $\begin{array}{l}13 \\
37\end{array}$ & $\begin{array}{l}10.16 \\
51.39\end{array}$ & 9.35 & 4.24 & 21.1 & $<0.001$ \\
\hline
\end{tabular}

Table 3 shows the results of the chisquare test of the correlation between treatment compliance in PLWHA with strong peer support groups (PGS) had 2.09 times treatment compliance compared to PLWHA who had a weak peer support group (OR= 2.09; $95 \% \mathrm{CI}=1.14$ to $3.85 ; \mathrm{p}<0.001)$. PLWHA who received family support had a 2.35 times treatment compliance compared to PLWHA who had weak family support for treatment $(\mathrm{OR}=2.35 ; 95 \% \mathrm{CI}=1.26$ to 4.40 ; $\mathrm{p}<0.001)$. PLWHA who had a high perceived benefit had 3.14 times treatment compliance compared to PLWHA who had a low per- ceived benefit of treatment $(\mathrm{OR}=3.14 ; 95 \%$ $\mathrm{CI}=1.68$ to $5.92 ; \mathrm{p}<0.001)$. PLWHA who had high perceived trust had 4.70 times treatment compliance than PLWHA who had low perceived trust for treatment $(\mathrm{OR}=4.70$; 95\% $\mathrm{CI}=2.40$ to $9.29 ; \mathrm{p}<0.001)$. PLWHA who had a low perceived barrier had 0.73 times treatment compliance compared to PLWHA who had high perceived barriers for treatment $(\mathrm{OR}=0.73 ; 95 \% \mathrm{CI}=0.40$ to $1.31 ; \mathrm{p}$ $<0.001)$. PLWHA, who had high observational learning, had a 1.79 times treatment compliance compared to PLWHA who had low 
Lobis et al./ Peer Support Group and Psychosocioeconomic Determinants on Treatment Compliance

observational learning for treatment. (OR= $1.79 ; 95 \% \mathrm{CI}=0.97$ to $3.30 ; \mathrm{p}<0.001)$.

\section{$\mathrm{C}$. The result of multilevel analysis}

The multivariate analysis explained the influence relationship between treatment compliance to PLWHA, peer support groups, family support, perceived benefits, perceived trust, perceived threats, perceived barriers, learning through observation.

Table 4. Path analysis of treatment compliance in PLWHA

\begin{tabular}{|c|c|c|c|c|c|c|}
\hline \multirow{2}{*}{$\begin{array}{l}\text { Dependent } \\
\text { Variable }\end{array}$} & & \multirow[b]{2}{*}{ Independent Variable } & \multirow[b]{2}{*}{ b } & \multicolumn{2}{|c|}{ 95\% CI } & \multirow[b]{2}{*}{$\mathbf{p}$} \\
\hline & & & & $\begin{array}{l}\text { Lower } \\
\text { limit }\end{array}$ & $\begin{array}{l}\text { Upper } \\
\text { limit }\end{array}$ & \\
\hline \multicolumn{7}{|l|}{ Direct effect } \\
\hline Treatment & $\leftarrow$ & Perceived Benefits & 1.10 & 0.41 & 1.79 & 0.002 \\
\hline compliance in & $\leftarrow$ & Perceived Barriers & -0.69 & -1.37 & -0.01 & 0.047 \\
\hline \multirow[t]{4}{*}{ PLWHA } & $\leftarrow$ & Perceived Trust & 1.56 & 0.85 & 2.27 & $<0.001$ \\
\hline & $\leftarrow$ & Peer Support Groups & 0.66 & -0.00 & 1.33 & 0.051 \\
\hline & $\leftarrow$ & Family Support & 0.97 & 0.28 & 1.66 & 0.006 \\
\hline & $\leftarrow$ & Perceived Threat & 1.09 & 0.41 & 1.77 & 0.002 \\
\hline Indirect effect & & & & & & \\
\hline $\begin{array}{l}\text { Perceived Trust } \\
\text { N observation }=200 \\
\text { Log-likelihood }=-231\end{array}$ & $\leftarrow$ & Observational Learning & 1.22 & 0.49 & 1.82 & $<0.001$ \\
\hline
\end{tabular}

Table 4 shows that there was an influence relationship between variables that can directly or indirectly affect treatment comliance to PLWHA. Treatment compliance to PLWHA was directly affected by perceived benefits $(b=1.10 ; 95 \% \mathrm{CI}=0.41$ to $1.79 ; \mathrm{p}=$ 0.002), perceived barrires ( $b=-0.69 ; 95 \% \mathrm{CI}$ $=-1.37$ to $-0.01 ; \mathrm{p}=0.047)$, perceived trust $(b=1.56 ; 95 \% \mathrm{CI}=0.85$ to $2.27 ; \mathrm{p}<0.001)$, peer support group $(b=0.66 ; 95 \% \mathrm{CI}=-0.00$ to $1.33 ; \mathrm{p}=0.051)$, family support $(\mathrm{b}=0.97$; $95 \% \mathrm{CI}=0.28$ to $1.66 ; \mathrm{p}=0.006)$, perceived threat $(b=1.09 ; 95 \% \mathrm{CI}=0.41$ to $1.77 ; \mathrm{p}=$ 0.002). Treatment compliance to PLWHA was influenced indirectly by learning through observation $(\mathrm{b}=1.22 ; 95 \% \mathrm{CI}=0.49$ to 1.82 ; $\mathrm{p}<0.001)$.

\section{DISCUSSION}

\section{The effect of perceived benefits on} treatment compliance in PLWHA

This study's results indicate that there was a direct effect of perceived benefit on treatment compliance in PLWHA, and it was statistically significant. PLWHA who had a high perceived benefit regarding treatment had an average (logodd) of treatment compliance 1.10 units higher than PLWHA who had a low perceived benefit $(b=1.10 ; 95 \% \mathrm{CI}=0.41$ to 1.79; $\mathrm{p}=0.002)$. This study's results are in line with a study conducted by Herlambang Sasmita Aji (2010),, which stated a relationship between perceived benefits between treatment compliance and antiretroviral therapy ( $\mathrm{p}<\mathrm{o.001}$ ). Besides, this study is in line with a study conducted by Rasmusen et al. (2013), which stated that ARV therapy's perceived benefits impacted patient treatment compliance.

This finding is in line with a study conducted by Yuniar (2012), which stated that the main internal factor that increased compliance to taking ARVs was PLHA's understanding of the benefits of understanding HIV / AIDS and its importance ARVs for PLWHA. Perceived benefits include a high understanding and awareness of the function and benefits of ARVs, strategies to consider drugs like vitamins so that PLWHA compliance in taking ARVs also increases. A study conducted by Miller et al. (2010) also found that patients universally reported that 
Lobis et al./ Peer Support Group and Psychosocioeconomic Determinants on Treatment Compliance

they had experienced extraordinary and even tremendous health benefits from taking ARVs and realized that stopping ARVs would cause disease.

\section{The effect of perceived barriers to treatment compliance in PLWHA}

This study's results indicate that there was a direct effect of perceived barriers on treatment compliance in PLWHA and statistically significant. PLWHA who had a high perceived barrier regarding treatment had an average (logodd) of treatment compliance 0.69 units lower than PLWHA who had a low perceived barrier $(b=-0.69 ; 95 \% \mathrm{CI}=-1.37$ to -0.01; $\mathrm{p}=0.047$ ). This study is in line with a study conducted by Sisyahid (2016), which stated that the perceived barriers did not cause non-adherence to ARV therapy, which means that the perceived barriers affect treatment compliance to PLWHA. This can be seen from most informants who did not experience significant obstacles in accessing ARVs or obstacles when taking ARVs. The perceived barriers can be minimized by the presence of good social support obtained by informants, support from families, support from NGOs, and support from health workers.

Based on HBM theory, perceived barriers are action behavior that will be formed from a person's perceived vulnerability and severity of the disease and the perceived benefits and obstacles faced. PLWHA, who consider the disease severity and have experienced serious symptoms, become more adherent in taking medication after knowing the benefits of ARVs. The high perceived barriers regarding HIV/AIDS information will make PLWHA more adherent to ARV treatment (Yuniar, 2012).

\section{The effect of perceived trust on treatment compliance in PLWHA}

The results of this study indicated that there was a direct effect of perceived trust on treatment compliance in PLWHA and statis- tically significant. PLWHA who had high perceived trust regarding treatment had an average (logodd) of treatment compliance 1.56 units higher than PLWHA who had low perceived trust $(b=1.56 ; 95 \% \mathrm{CI}=0.85$ to 2.27; $\mathrm{p}<0.001$ ).

Trust is a belief about the truth about something that is felt in the culture that exists in that society. So that if people have wrong beliefs about something, it can hinder behavior change (Beauty, 2016). The health belief model is where a person acts to avoid and control disease when someone thinks that humans have a vulnerable condition, that illness has serious consequences, and believes that action can reduce vulnerability and seriousness. Actions will be worth the benefits (Sudomo, 2020).

This study explained that high perceived trust could increase PLWHA treatment compliance. PLWHA believes that by consuming ARVs every day, their quality of life will be better and safer if they take ARVs every day and feel healthy carrying out their daily activities. Thus, trust encourages PLWHA to be more obedient in consuming ARV every day. This result is supported by Glanz's (2012) theory, which stated that a trust influenced compliance included in health behavior. Where there was trust, there was an effort to avoid the disease even though it was related to finance.

\section{The effect of peer support groups on treatment compliance in PLWHA}

This study's results indicate that there was a direct effect of peer support groups on treatment compliance in PLWHA and statistically significant. PLWHA, who had a strong peer support group regarding treatment, had an average (logodd) of treatment compliance o.66 units higher than PLWHA, who had a weak peer support group $(b=0.66 ; 95 \% \mathrm{CI}=$ 0.00 to $1.33 ; \mathrm{p}=0.051)$. This study's results are in line with a study conducted by Tri Johan et al. (2001), which stated that there 
Lobis et al./ Peer Support Group and Psychosocioeconomic Determinants on Treatment Compliance

was a significant influence between the role of peer support groups and treatment compliance in PLWHA.

Research in the Bulletin of Health Research (2013) stated that peer support groups were very helpful in taking treatment compliance with PLWHA. The role of Peer Support Groups (PGS) is very helpful for PLWHA, especially in terms of undergoing treatment, providing motivation for PLWHA to always be cooperative in counseling and treatment. This is in accordance with Alfiyyatur (2012), who stated that PGS has the task of providing motivation and assisting PLWHA, namely informing in-depth about HIV/AIDS, including taking ARV drugs.

A theory from Yuswanto et al. (2015) stated that a peer support group is a group that aims to support each group member in their daily life. Peer support includes people who face the same challenges, e.g., patients with certain infections, certain communities. Peer Support Groups (PGS) are well known in HIV/AIDS prevention to provide support for people infected with HIV (PLWHA) and their families. The first time someone finds themselves infected with HIV, they have several psychological, health concerns, relationships with partners, economics, and prejudice. They will be treated with stigma and discrimination. The moral support needed by people infected with HIV is needed to overcome these various problems to still live healthy and productive lives.

Peer support interventions in HIVinfected adolescents have shown a correlation with emotional management and positively influence treatment outcomes. This conclusion was obtained by comparing groups of adolescents who were intervened and not intervened through peer support activities. Within 2 years, it shows a change in perceptions of pain and concerns about illness in the adolescent group in the peer support group, and a further increase in the number of adolescents whose virus is not detected through viral load testing (Isabelle, 2015).

\section{The effect of family support on treatment compliance in PLWHA}

This study's results indicate that there was a direct effect of family support on treatment compliance in PLWHA and statistically significant. PLWHA who had strong family support regarding treatment had an average (logodd) treatment compliance 0.97 units higher than PLWHA who had a weak family support group $(\mathrm{b}=0.97 ; 95 \% \mathrm{CI}=0.28$ to 1.66; $\mathrm{p}=0.006)$. This study's results are in line with Bachrum's (2017) study, which stated that there was a correlation between family support and compliance with taking ARV drugs in PLWHA at PGS Sehati.

Family support is needed because PLWHA will experience boredom, so they don't feel hopeless. It is hoped that family support can support PLWHA's spirit of life who can control their emotions. Emotional support gives individuals a feeling of comfort, feeling loved when experiencing depression, and assistance in enthusiasm, empathy, trust, and attention. The individual who receives it feels valuable. In this emotional support, the family provides a place to rest and gives encouragement (Prasetyawati, 2011).

Other studies also support the results of this study. The level of family support experienced by respondents affects compliance; the greater the level of family support, the greater the compliance to taking ARV drugs significantly. Family plays an important role in improving, helping, and encouraging patients to comply with the treatment journey (Lumbanbatu, 2012).

According to the Ministry of Health (2011), the couple and their families will provide support and care. This relationship can affect compliance because if the family provides motivation and provides support, it includes: instrumental support, informa- 
Lobis et al./ Peer Support Group and Psychosocioeconomic Determinants on Treatment Compliance

tional support, assessment support, and emotional support for the patient, and there must be openness between the patient and the family so that the family understands the patient's needs and vice versa (Ministry of Health, 2011). Family support is one of the motivations for HIV/AIDS sufferers apart from the hospital's programs in undergoing treatment programs and family support, which is given in the form of attention and provides an explanation of suggestions that can motivate patients to undergo HIV / AIDS treatment programs.

\section{The effect of perceived threats on treatment compliance in PLWHA}

This study's results indicate that there was a direct effect of perceived threat on treatment compliance in PLWHA, and it was statistically significant. PLWHA who had a high perceived threat regarding treatment had an average (logodd) of treatment compliance 1.09 units higher than PLWHA who had a low perceived threat $(b=0.97 ; 95 \% \mathrm{CI}=0.28$ to $1.66 ; \mathrm{p}=0.006)$. This is in line with Marpaung's (2016) study regarding factors related to HIV/AIDS patient compliance, namely respondents who had a higher perceived threat, namely 57 respondents (81.4\%) from a total of 70 respondents.

Someone will take action to cure the disease if the disease truly threatens them. In this case, HIV/AIDS is a disease that is a threat to anyone, especially PLWHA (Saputro, 2016). This is the basis why individual perceptions of the severity of disease and self-belief can change individual behavior to be more useful in the treatment process, namely, by being more obedient (Novianto, 2016).

This theory is also supported by Lestari (2017), who stated that perceived threat comes from beliefs about the seriousness of the disease and the vulnerability of PLWHA. The individual then assessed the benefits of the action taken, namely adherence to following ARV treatment, even though PLWHA is overshadowed by the risks of their actions, such as fear and drug side effects.

\section{The effect of learning through obser- vation on treatment compliance in PLWHA}

The results showed an indirect effect of learning through observation on treatment compliance to PLWHA through the perception of trust. PLWHA who had high experiential learning about treatment had an average (logodd) of treatment compliance 1.22 units higher than PLWHA who had low observational learning $(b=1.22 ; 95 \% \mathrm{CI}=0.62$ to 1.82; $\mathrm{p}<0.001$ ).

The best learning for adults is observational learning. Learning through observation means learning to face practical problems, real social problems, and solve them. Good observation of someone will create a sense of trust (Arif, 2014). Perceived benefits are the belief in the advantages of the suggested methods to reduce the risk of disease. Perceived benefits, in summary, mean the perceived benefits which have a positive relationship with healthy behavior. Individuals aware of the benefits of ARVs consumed by PLWHA will continue to carry out healthy behaviors such as routine daily ARV consumption (Wulandari, 2015).

\section{AUTHOR CONTRIBUTION}

Yusuf Bachtiyar Lobis was the main researcher who collected data, formulated data, designed the research and conducted questionnaire reliability tests. Bhisma Murti checked the data and analyzed the data. Hanung Prasetya gave suggestions for discussion of research and writing techniques.

CONFLICT OF INTEREST

There is no conflict of interest in this study. 
Lobis et al./ Peer Support Group and Psychosocioeconomic Determinants on Treatment Compliance

\section{FUNDING AND SPONSORSHIP}

This study used the main researcher's funds and the 2018 Ministry of Health's 'Tugas Belajar' scholarship.

\section{ACKNOWLEDGEMENT}

The authors would like to express their gratitude to the Sragen Regency Health Office and the Peer Support Group in Sragen Regency, the PGS cadres who had helped this research, and respondents represented by PLWHA have become the study subjects.

\section{REFERENCE}

Alfiyyatur R (2012). Peran Buddy Sebagai Pendamping ODHA. Retrieved from http://www.kompas.com. Jakarta 2012. retrieved 13-08-2020.

Arif B (2014). Faktor yang mempengaruhi kepatuhan berobat pasien yang diterapi dengan temoxifen setelah operasi kanker payudara. Jurnal Kesehatan Andalas, 2(1):20-24. https://doi.org/10.25077/jka.v2i1.6o.

Bachrun E (2017). Hubungan dukungan keluarga dengan kepatuhan minum obat antiretroviral pada orang dengan HIV/AIDS (ODHA). Jurnal TRIK (Tunas-Tunas Riset Kesehatan), 7(1): 12-16. Retrieved from http://2trik.jurnalelektronik.com/index.php/2trik/article/view/61. ISSN: 2089:4686.

Beauty AL (2016). Hubungan antara persepsi dan dukungan keluarga dengan kepatuhan minum obat pasien baru tuberkulosis paru (Studi Kasus Di Puskesmas Majebo Kabupaten Kudus). Tesis. Semarang: UNNES.

Dinas Kesehatan Kabupaten Sragen (2017). Profil kesehatan dinas kesehatan kabupaten sragen tahun 2017. Sragen : DKK Sragen.

Dinas Kesehatan Kabupaten Sragen (2019). Data Kasus HIV AIDS di Wilayah Kabupaten Sragen. Sragen: DKK Sragen.
Glanz K, Barbara KR, Frances (2012). Health Behavior \& Health Education Theory, Research, \& Practise. San Fransisco: Jossey Bass.

Isabelle $\mathrm{FB}, \mathrm{Ce}^{\prime}$ cile $\mathrm{D}$, Vebera F, Quartiera $\mathrm{P}$, Hefeza S, Costagliolab D, Blanche S (2015). Evaluation of a peer support group therapy for HIV-infected adolescents. AIDS Care. 19(14):1501-8. https://doi.org/10.1097/o1.aids.0000183124.86335.0a.

Johan T, Wahyuni T, Pitoyo J (2014). Hubungan Peran KDS (Kelompok Sebaya) Dengan Kepatuhan Minum Obat Pada ODHA. (Laporan Penelitian RISBINAKES Poltekes Kemenkes Malang).

Kementerian Kesehatan Republik Indonesia (2011). Pedoman Nasional Tatalaksana Klinis Infeksi HIV dan Terapi Antiretroviral pada Orang Dewasa. Jakarta: Kementrian Kesehatan Republik Indonesia.

Kementerian Kesehatan Republik Indonesia (2013). Peraturan Menteri Kesehatan Republik Indonesia Nomor 21 Tahun 2013 Penanggulangan HIVAIDS. Jakarta: Kementerian Kesehatan Republik Indonesia.

Kementerian Kesehatan Republik Indonesia (2018). Laporan HIV-AIDS di Indonesia. Jakarta: Kementerian Kesehatan Republik Indonesia.

Lestari DA (2017). Hubungan antara risk perception, outcome expectancies dan task self-efficacy dengan kepatuhan ODHA dalam terapi antiretroviral di Puskesmas Dupak Surabaya. Tesis. Surabaya: Universitas Airlangga.

Lumbanbatu V, Linda TL (2012). Faktorfaktor yang berhubungan dengan kepatuhan ODHA Dalam Menjalani Terapi Antiretroviral Di RSU Dr. Pringadi Medan. Retrieved from: https://jurnal.usu.ac.id/index.php/kpkb/article/view/3780. 
Lobis et al./ Peer Support Group and Psychosocioeconomic Determinants on Treatment Compliance

Marpaung IRL (2016). Faktor-faktor yang berhubungan dengan kepatuhan pasien HIV/AIDS dalam menjalani terapi antiretroviral di RSU Haji Medan tahun 2016. Tesis. Medan: Universitas Sumatera Utara.

Miller CM, Ketlhapile M, Rybasack-smith H, Rosen S (2010). Why are antiretroviral treatment patients lost to follow-up? A qualitative study from South Africa. Trop Med Int Health. 15(s1):48-54. https://doi.org/10.1111/j.1365-3156.2010.02514.x.

Novianto AE (2016). Gambaran faktor-faktor yang mempengaruhi kepatuhan konsumsi ARV pada ODHA di BPKM Wilayah Semarang. Semarang: Sekolah Tinggi Ilmu Kesehatan Ngudi Waluyo Ungaran.

Prasetyawati E (2011). Ilmu kesehatan masyarakat untuk kebidanan holistik. Yogyakarta: Nuha Medika.

Rasmusen DN, Silva DT, Rodkjaer L, Oliveira I, et al. (2013). Barrier and facilitators to antireteroviral therapy adherance among patients with HIV in BissauGuinea Bissau: A qualitative study. Afr J AIDS Res. 12(1):1-8. https://doi.org/10.2989/16085906.2013.815405.

Saputro AIP (2016). Faktor-faktor yang berhubungan dengan kepatuhan ODHA dalam menjalankan terapi ARV di RSPAD Gatot Soebroto Jakarta Pusat. Tesis. Manado: Universitas Sam Ratu- langi.

Sisyahid AK (2016). Faktor yang menyebabkan terjadinya ketidakpatuhan terapi antireteroviral (ARV) pada Orang dengan HIV/AIDS (ODHA) di Kabupaten Pemalang. Tesis. Semarang: Universitas Negeri Semarang.

Sudomo (2020). Model Kepercayaan Kesehatan (Health Beliefs Model). Jakarta: Universitas Gunadarma Press.

Wulandari HD (2015). Analisis faktor-faktor yang berhubungan dengan kepatuhan pasien tuberkulosis paru tahap lanjutan untuk minum obat di RS Rumah Sehat Terpadu Tahun 2015. Jurnal Administrasi Rumah Sakit. 2(1):1-5. http://= dx.doi.org/10.7454/arsi.v2i1.2186.

Yuniar Y, Handayani R, Aryastami (2013). Faktor-faktor pendukung kepatuhan orang dengan HIV AIDS (ODHA) dalam minum obat antiretroviral di Kota Bandung dan Cimahi. Buletin Of Health Research, 41(2): 72-83. Retrieved from Ejournal.litbang.depkes.go.id.

Yuswanto A, Wahyuni TD, Pitoyo J (2015). Peran kelompok dukungan sebaya (KDS) dan kepatuhan minum obat pada ODHA. Jurnal Pendidikan Kesehatan. 4(1): 64-69. Retrieved from: https://adoc.pub/peran-kelompokdukungan-sebaya-kds-dan-kepatuhanminum-obat-.html. 